\title{
The Analysis of Students' Difficulties in Solving Problems of Probability for $8^{\text {th }}$ Grade
}

\author{
Seftika Anggraini \\ Mathematics Education, Faculty of Mathematics and \\ Natural Science \\ Yogyakarta State University \\ Yogyakarta, Indonesia \\ seftika96@gmail.com,
}

\author{
Endah Kusrini \\ Mathematics Education, Faculty of Mathematics and \\ Natural Science \\ Yogyakarta State University \\ Yogyakarta, Indonesia \\ , endahkusrini96@gmail.com
}

\begin{abstract}
Probability is one part of mathematics material that is learned in school. In Indonesia, probability is learned from Junior High School level and is continued in Senior High School level. Hence, understanding of probability's concept in Junior High School level is very important. The aim of this research is to analyze students' difficulties of $8^{\text {th }}$ Grade of SMPN 1 Prambanan Klaten in solving problems of probability. The method used in this research is descriptive method. Data collection was done based on students' work through essay test. The result shows that the difficulties which are experienced by the students in solving pobability's problem are the difficulty in understanding proportional reasoning and the difficulty in resolving misconceptions or misperceptions in probability. The misconceptions are representativeness, probability cannot be measured mathematically, misuse or extend conclusions inappropriately, inappropriate reasons, beliefs, equi-probability bias, and possible means certain.
\end{abstract}

Keywords-Analysis; Students'difficulties; Probability

\section{INTRODUCTION}

Probability is one part of mathematics material that is learned in school. Based on Indonesia's curriculum, probability for the first time is learned in Junior High School level and is continued in Senior High School level. Hence, understanding of probability's concept in Junior High School level is very important.

According to Xiayan probability is a branch of mathematics which utilizes the principles of addition and multiplication (combinatorial mathematics principle) to do pure digit arithmetic during the calculation process [1]. Besides, Sultan and Artzt stated that the study of probability is the study of proportion that makes claims about likelihood or chance of certain events occurring and this why probability is often defined as the study of chance [2]. Therefore, it can be concluded that probability is branch of mathematics which is about proportion to make claims about chance of certain events by using addition and multiplication principles.

National Council of Teachers of Mathematics stated that students in Grades 6-8 should understand and apply basic concepts of probability, which consist of [3]:
- understand and use appropriate terminology to describe complementary and mutually exclusive events;

- use proportionality and a basic understanding for probability to make and test conjectures about the results of experiments and simulations;

- compute probabilities for simple compound events, using such methods as organized lists, tree diagrams, and area models.

Meanwhile, based on Indonesia's curriculum, probability is learned by $8^{\text {th }}$ grade students. In the curriculum, students must capable to [4]:

- explain empirical and theoretical probabilities of an event.

- solve problems about empirical and theoretical probabilities of an event.

While students solve problem of probability, they tend to have perceptions which hinder their learning of probability concepts [5]. In addition, the types of misconceptions while student solving problems probability as follows [5]:

1. Representativeness: students tend to incorrectly think that samples which correspond to the population distribution are more probable than samples which do not. For example in tossing a coin, students with this misperception will think that a series of coin tosses that has approximately equal numbers of heads and tails is more probable than a series with many more tails than heads. However, the probability for both series is the same.

2. Equi-probability bias: students tend to assume that random events are equally probable by nature. For example, students with this misperception will think that three sixes or one six on three rolls of a die are viewed as equally likely occur.

3. Beliefs: students think that eventual outcome of an event depends on a force which is beyond their control. Sometimes this force is God or some other force such as wind, other times luck or wishes.

4. Human control: students think that their results depend on how one throws or handles these different device while they 
generalise the behaviour of random generators such as dice, coins, and spinners.

Meanwhile, according to Jun and Pereira-Mendoza's observation [6], students' misconceptions in solving problems of probability were (1) subjective judgements; (2) examplebased interpretations for possible and impossible; (3) possible means certain; (4) chance cannot be measured mathematically; (5) equi-probability; (6) outcome approach; (7) one trial is unrelated to other trials; (8) interpreting chance by data matching or word matching; (9) increasing repetitions is not better for predicting; (10) positive and negative recency; (11) use own methods in chance comparison; (12) taking different order as the same; (13) misuse or extend conclusions inappropriately; and (14) use own methods of chance calculation.

Mastery concept of probability can be reflected from Trends in International Mathematics and Science Study (TIMSS) results. TIMSS is an international assessment of mathematics and science at the fourth and eighth grades that has been conducted every four years since 1995 [7]. The interval score for every topic has a range of 0-1,000. Based on TIMSS report, mathematics scores of eighth grade in Indonesia for every topic are shown in Table 1:

TABLE I. MATHEMATICS SCORES OF EIGHT GRADE IN INDONESIA

\begin{tabular}{|c|c|c|c|c|}
\hline \multirow{2}{*}{ Year } & \multicolumn{4}{|c|}{ The Average Scores } \\
\cline { 2 - 5 } & Number & Algebra & Geometry & $\begin{array}{c}\text { Data and } \\
\text { Probability }\end{array}$ \\
\hline 2007 & 393 & 399 & 387 & 382 \\
\hline 2011 & 375 & 392 & 377 & 376 \\
\hline
\end{tabular}

Based on the table above, data and probability were on the lowest score of others topic for two periods. Thus, it can be concluded that data and probability are the most difficult materials for students in Indonesia.

In other hand, national final exam is used to assess students' conceptual knowledge in Indonesia. The achievement in Probability of SMPN 1 Prambanan is shown in the figure 1 [8][9][10][11].

\section{Percentage of Achievement in Probabilty}

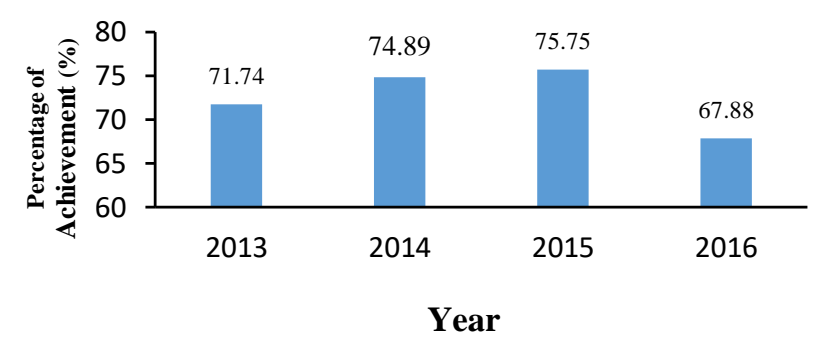

Fig. 1. Percentage of students' achievement in probability on national exam.

From the chart above, the percentage of students' achievement in 2013, 2014, and 2015 were $71.74 \%, 74.89 \%$, and $75.75 \%$ respectively. It were shown that the percentage from 2013 until 2015 increased. The percentage of students' achievement in 2016 were $67.88 \%$. It were shown that the percentage from 2015 to 2016 decreased. Therefore, based on the data above, it is necessary to conduct a research which aim for analyze students' difficulties of $8^{\text {th }}$ Grade of SMPN 1 Prambanan Klaten in solving problems of probability.

\section{RESEARCH METHOD}

This research used descriptive approach. The aim of this research is to analyze students' difficulties in solving problems of probability. The subject of this research is 348 th grade students of SMPN 1 Prambanan Klaten. Data collection was done based on students' work through essay test which consist of six items. The instrument was arranged based on probability's basic competence of 8th grade in national curriculum.

Analysis data is conducted by calculating the average of each item then it is converted to a scale of 5 . Below is guide of conversion by using five scales [12].

TABLE II. GUIDE OF CONVERSION SCALE

\begin{tabular}{|c|c|}
\hline Formula & Category \\
\hline$X>\bar{X}_{l}+1.8 \times s b_{i}$ & Very Good \\
\hline $\bar{X}_{l}+0.6 \times s b_{i}<X \leq \bar{X}_{l}+1.8 \times s b_{i}$ & Good \\
\hline $\bar{X}_{l}-0.6 \times s b_{i}<X \leq \bar{X}_{l}+0.6 \times s b_{i}$ & Enough \\
\hline $\bar{X}_{l}-1.8 \times s b_{i}<X \leq \bar{X}_{l}-0.6 \times s b_{i}$ & Less Good \\
\hline$X \leq \bar{X}_{l}-1.8 \times s b_{i}$ & Very Less \\
\hline \\
\hline \multirow{2}{*}{\multicolumn{2}{|c|}{$\begin{array}{l}=\text { ideal mean } \\
=\frac{1}{2}(\text { maximum score }+ \text { minimum score })\end{array}$}} \\
\hline & \\
\hline \multicolumn{2}{|c|}{$=$ standard deviation } \\
\hline \multicolumn{2}{|c|}{$=\frac{1}{6}($ maximum score - minimum score $)$} \\
\hline \multicolumn{2}{|l|}{$=$ mean score } \\
\hline
\end{tabular}




\section{RESULTS AND DISCUSSION}

From the students' work, it is analysed to know the category and the difficulties in each item. The result of students' work for each item is shown in Table III.

Based on Table III, the average of students' achievement in probability is on good category. It means that students can achieve the learning objective that explain and solve problems about empirical and theoretical probabilities of an event. Although, basic competency score of explaining is better than solving problems. The results show that the students easy to understand concept of empirical and theoretical probabilities but difficult to solve problems about empirical and theoretical probabilities.

For the first question, it is on very good category. It means that the student can solve problem about probability concept (probability has no memory) very well. However, according to students' responses, some students thought that probability's value depended on the result of event before. This misconception can also be called as representativeness [5]. Besides, there were students' response that probability of an event is an accident. It means probability cannot be measured mathematically [6].

TABLE III. RESULT OF STUDENTS' WORK

\begin{tabular}{|c|c|c|c|c|}
\hline Basic Competency & Indicator & Question No. & Average Score & Category \\
\hline \multirow{3}{*}{$\begin{array}{l}\text { Explaining empirical and } \\
\text { theoretical probabilities } \\
\text { of an event }\end{array}$} & $\begin{array}{l}\text { Solving problem about probability concept } \\
\text { (probability has no memory) }\end{array}$ & 1 & 4.20 & Very Good \\
\hline & $\begin{array}{l}\text { Determining sample space of an event by } \\
\text { using various methods (listing, tree } \\
\text { diagram, or table) }\end{array}$ & 2 & 5.47 & Very Good \\
\hline & Determining example of fair games & 3 & 4.38 & Very Good \\
\hline \multirow{4}{*}{$\begin{array}{l}\text { Solving problems about } \\
\text { empirical and theoretical } \\
\text { probabilities of an event }\end{array}$} & $\begin{array}{l}\text { Making conclusion based on concept of } \\
\text { probability's value }\end{array}$ & 4 & 2.65 & Enough \\
\hline & $\begin{array}{l}\text { Determining probability's value of complex } \\
\text { event }\end{array}$ & 5 & 2.76 & Enough \\
\hline & $\begin{array}{l}\text { Solving problem about empirical } \\
\text { probability }\end{array}$ & 6 & 4.68 & Good \\
\hline & & 1 until 6 & 24.20 & Good \\
\hline
\end{tabular}

The second question is on very good category. It means that the student can determine sample space of an event by using various methods (listing, tree diagram, or table) very well. However, there was student who gave response inappropriately. This response is classified in the misuse or extend conclusions inappropriately category [6].

The third question is also on very good category. It means that the student can determine example of fair games by using probability concept very well. However, some students gave inappropriate reasons of the problem. Some students also gave incomplete response. They only chose one of four option which is given, where there were three fair games.

From question number 1 until 3, it can be conclude that the students can explain problems about empirical and theoretical probabilities of an event very well. Students have known the basic concept of probability such as determining sample space of an event, determining the value of empirical and theoretical probabilities of an event.

The fourth question is on enough category. It means that the students can make conclusion based on concept of probability adequately. Since they were fooled to the question, mostly students gave inappropriate responses where only three students gave the right answer. The students were fold on deciding the truth of conclusion of the problem whereas it was wrong conclusion. Moreover, the students did not understand the probability's value given in another form, in this case in percentage form. This difficulty was more a difficulty in understanding proportional reasoning and how a numerical value can be expressed as others forms [13]. There was students who gave reason that the event depends on a force which is beyond their control. This response is classified in the belief category [5].

The fifth question is on enough category. It means that the students can determine probability's value of complex event adequately. There was only a student who gave the right answer. Mostly students gave the wrong answer by using their own method to compute the probability. It is difficult to the students to compute the probability of random events while role two dice. Some students viewed several outcomes of an experiment as equally likely. Type of this misconception refers to equiprobability bias category [1][5][6].

The sixth question is on good category. It means that the students can solve problem about empirical probability well. Overall, the students compute the probability's value correctly but they made conclusion inappropriately [6]. Since the successful event was greater than unsuccessful event, students thought the probability as a certain. This misperception refers to possible means certain category [6]. Moreover, some students also had difficulty in calculating fraction.

\section{CONCLUSION}

According to the analysis above, overall, the result of students' work is on good category. However, it is found some students' difficulties while solve the probability's problem. The difficulties are the difficulty in understanding proportional reasoning and the difficulty in resolving misconceptions or misperceptions in probability. The misconceptions are 
representativeness, probability cannot be measured mathematically, misuse or extend conclusions inappropriately, inappropriate reasons, beliefs, equi-probability bias, and possible means certain.

The concept of probability is a new concept for junior high school students, however, students basically have had basic concept which is used in learning probability. The concept is about numerical reasoning as express a ratio, a fraction, a decimal, or a percentage. Thus, numerical reasoning of students need to be improved so that students can understand the concepts of probability well. In addition, there are two teaching practises to help students in understanding the concept of probability. The first is incorporating a hierarchy of questions to help students contrast a stronger and greater understanding of the topic. The second is to highlight and revise proportional reasoning so that the students understand how a similar numerical value can be represent in different ways [13].

\section{REFERENCES}

[1] S. Xiayan, "An analysis of difficulties in learning probability in high school," $7^{\text {th }}$ ICMI-East Asia Regional Conference on Mathematics Education. Philippines, 2015, pp. 561-568, in press.

[2] A. Sultan and A.F. Artzt, The Mathematics that Every Secondary School Math Teacher Needs to Know. New York: Routledge, 2011.

[3] National Council of Teachers of Mathematics, Principles and Standards for School Mathematics. Reston, VA: NCTM, Inc., 2000.

[4] Kemendikbud, Peraturan Menteri Pendidikan dan Kebudayaan No. 24 Tahun 2016, 2016.

[5] L.H. Ang and M. Shahrill, "Identifying students' specific misconceptions in learning probability," IJPS, 2014, pp. 23-29, in press.

[6] L. Jun and L. Pereira-Mendoza, "Misconceptions in probability," ICOTS6, 2002, in press.

[7] I.V.S. Mullis, M.O. Martin, P. Foy, and A. Arora, TIMSS 2011 International Results in Mathematics. Amsterdam: Lynch School of Education, 2012.
[8] BSNP. Laporan Hasil Ujian Nasional Tahun Pelajaran 2012/2013, 2013.

[9] BSNP. Laporan Hasil Ujian Nasional Tahun Pelajaran 2013/2014, 2014.

[10] BSNP. Laporan Hasil Ujian Nasional Tahun Pelajaran 2014/2015, 2015.

[11] Puspendik. Laporan Hasil Ujian Nasional Tahun Pelajaran 2015/2016, 2016.

[12] E.P. Widoyoko, Evaluasi Program Pembelajaran. Yogyakarta: Pustaka Pelajar, 2009.

[13] I. Hay, "Teaching probability: using levels of dialogue and proportional reasoning," ICOTS9, 2014, pp. 1-3, in press 